\title{
Pengaruh Berbagai Varietas dan Tinggi Muka Air Terhadap Pertumbuhan dan Hasil Padi (Oryza sativa L.) Pada Tanah Alluvial
}

\author{
The Effect of Various Varieties and Water Levels on The Growth and Yield of Rice
} (Oryza sativa L.) In Alluvial Soil

\author{
Author(s): Erlianus ${ }^{(1)}$ Radian $^{(1)^{*}}$; Tris Haris Ramadhan ${ }^{(1)}$ \\ (1) Jurusan Budidaya Pertanian, Fakultas Pertanian Universitas Tanjungpura Pontianak \\ * Corresponding author: erlianusbky07@gmail.com
}

\section{Submitted: 10 Dec $2020 \quad$ Accepted: 01 Jun $2021 \quad$ Published: 30 Sep 2021}

\begin{abstract}
ABSTRAK
Ketersediaan air mempengaruhi faktor pertumbuhan tanaman padi yaitu fisiologi, morfologi, pola pertumbuhan dan hasil padi. Tujuan penelitian ini adalah mengetahui respon beberapa varietas padi sawah dengan tinggi muka air yang berbeda dan mendapatkan varietas padi sawah yang terbaik dan tinggi muka air yang sesuai terhadap hasil tanaman padi sawah. Penelitian lapang ini dilaksanakan di Desa Cipta Karya, Kecamatan Sungai Betung, Kabupaten Bengkayang. Penelitian dilaksanakan selama lima bulan, sejak bulan Februari sampai Juni 2020. Penelitian ini menggunakan metode eksperimen lapangan dengan pola Rancangan Acak Lengkap Faktorial (RALF) yang terdiri dari 2 faktor dan diulang sebanyak 3 kali. Faktor pertama adalah varietas padi (V) sebanyak 4 taraf yaitu varietas Cilosari, Ciherang, Inpari 39 dan Inpago 8 dan faktor kedua adalah tinggi muka air (A) sebanyak 5 taraf yaitu $-5 \mathrm{~cm}, 0 \mathrm{~cm}$, $5 \mathrm{~cm}, 10 \mathrm{~cm}$ dan $15 \mathrm{~cm}$. Pengamatan tanaman meliputi tinggi tanaman, jumlah anakan maksimum, jumlah anakan produktif, umur berbunga, jumlah gabah isi per malai, panjang malai, persentase gabah isi per malai, bobot 1.000 butir dan bobot gabah kering panen per rumpun. Hasil penelitian menunjukkan varietas dan tinggi muka air sangat berpengaruh nyata terhadap komponen pertumbuhan yaitu tinggi tanaman, jumlah anakan maksimum Varietas Cilosari, Inpari 39 dan Inpago 8 memberikan bobot gabah tertinggi yaitu masing-masing sebesar 36,93, 32,40 dan 31,89 g per rumpun. Perlakuan tinggi muka air $5 \mathrm{~cm}$ memberikan bobot gabah tertinggi sebesar $37,92 \mathrm{~g}$ per rumpun.
\end{abstract}

\section{Kata Kunci:}

alluvial,

padi,

tinggi muka air,

varietas
Keywords:

alluvial,

rice,

varieties,

water level

\section{ABSTR $A C T$}

Water availability affects the growth factors of rice plants, namely physiology, morphology, growth patterns and rice yields. The purpose of this study was to determine the response of several lowland rice varieties with different water levels and to obtain the best lowland rice varieties and the appropriate water levels for lowland rice yields. This field research was conducted in Cipta Karya Village, Sungai Betung District, Bengkayang Regency. The research was conducted for five months, from February to June 2020. This study used a field experiment method with a completely randomized factorial design (RALF) which consisted of 2 factors and was repeated 3 times. The first factor is 4 levels of rice varieties (V), namely Cilosari, Ciherang, Inpari 39 and Inpago 8 varieties and the second factor is the water level (A) of 5 levels, namely $-5 \mathrm{~cm}, 0 \mathrm{~cm}, 5 \mathrm{~cm}, 10 \mathrm{~cm}$ and $15 \mathrm{~cm}$. Plant observations including plant height, maximum number of tillers, number of productive tillers, flowering age, number of filled grains per panicle, length of panicle, percentage of filled grain per panicle, weight of 1,000 grains and weight of harvested dry grain per clump. The results showed that the variety and water level had a significant effect on the growth components, namely plant height, the maximum number of tillers. Cilosari, Inpari 39 and Inpago 8 varieties gave the highest grain weight, namely 36.93, 32.40 and $31.89 \mathrm{~g}$ per clump, respectively. The $5 \mathrm{~cm}$ water level treatment gave the highest grain weight of $37.92 \mathrm{~g}$ per clump. 


\section{PENDAHULUAN}

Program peningkatan ketahanan pangan menjadi target utama pemerintah dalam memenuhi kebutuhan terutama beras masyarakat Indonesia. Provinsi Kalimantan Barat merupakan salah satu sentra padi yang memberikan kontribusi terhadap produksi beras nasional dengan luas panen padi pada tahun 2017 sebesar 214.877 hektar dan total produksi padi sebesar 622.041 ton GKG dengan produktivitas padi sebesar 2,89 ton/ha (Badan Pusat Statistik Kalimantan Barat, 2018). Produktivitas padi di Kalimantan Barat masih rendah, data produktivitas padi secara nasional pada tahun 2017 mencapai 5,18 ton/ha (Badan Pusat Statistik Kalimantan Barat, 2018). Untuk memenuhi kebutuhan pangan di masa yang akan datang, perlu dilakukan perbaikan teknologi budidaya yang tepat dalam meningkatkan produksi pangan.

Upaya peningkatan produktivitas tanaman padi di Kalimantan Barat salah satunya dihadapkan pada kendala faktor lingkungan yaitu fluktuasi ketersediaan air. Hasil identifikasi di lapangan khususnya di Kabupaten Bengkayang sebagian besar pada lahan sawah sistem pengairan atau irigasi belum permanen sehingga khususnya di Kabupaten Bengkayang pada musim hujan beberapa lahan tergenang dan pada musim kemarau mengalami kekeringan. Selain itu juga terdapat tipe lahan sawah tadah hujan yang ketersediaan airnya masih mengandalkan sepenuhnya dari curah hujan.

Kebutuhan air tanaman padi ditentukan oleh beberapa faktor seperti jenis tanah, kesuburan tanah, iklim (basah atau kering), umur tanaman, dan varietas padi yang ditanam, dan sebagainya. Inovasi teknologi yang dapat dilakukan untuk mengatasi ketersediaan air pada lahan sawah antara lain memilih varietas padi yang sesuai dan dapat beradaptasi pada kondisi lingkungan tersebut. Air memiliki peranan yang penting pada saat pembentukan anakan, inisiasi malai, pertumbuhan akar dan penyerapan mineral (Purba, 2011).

Kekurangan air dapat menyebabkan tanaman menjadi kerdil dan lambat dalam pertumbuhan, perkembangannya menjadi lambat dalam pertumbuhan sehingga perkembangannya menjadi tidak optimal. Kekurangan air yang terjadi secara terusmenerus selama periode pertumbuhan akan menyebabkan tanaman terhambat proses pertumbuhan dan kemudian mati. Biasanya kekurangan air pada tanaman dapat terlihat secara nyata yaitu layunya daun-daun. Peristiwa kelayuan ini disebabkan karena penyerapan air tidak dapat mengimbangi kecepatan penguapan air dari tanaman (Bray, 2007).

Pemberian air yang berlebihan terutama pada lahan sawah dengan penggenangan yang secara terus menerus dari sejak bibit padi ditanam sampai tanaman mendekati waktu panen, baik pada pertanaman musim hujan maupun musim kemarau dapat menimbulkan pemborosan penggunaan air. Di sisi lain, penggenangan air secara terus menerus pada beberapa varietas padi menyebabkan pengurangan kadar oksigen dalam tanah sehingga terbentuknya senyawa-senyawa beracun dalam tanah seperti: Al, Fe, asamasam organik, dan $\mathrm{H}_{2} \mathrm{~S}$, yang dapat meracuni tanaman sehingga tanaman menjadi kerdil (Hardjowigeno \& Rayes, 2005). Sebaliknya beberapa varietas yang mengalami kekeringan berdampak serius terhadap pertumbuhannya, terutama pada fase generatif dan tanaman padi sangat sensitif terhadap cekaman kekeringan. Kekurangan air menyebabkan terganggunya berbagai fungsi seluler dalam tanaman dan berdampak negatif terhadap pertumbuhan dan reproduksi tanaman.

Tujuan penelitian ini adalah membandingkan respon pertumbuhan dan produksi beberapa varietas padi sawah dengan tinggi muka air yang berbeda. 
Berdasarkan hasil penelitian diperoleh varietas padi dan tinggi muka air terbaik yang dapat meningkatkan produksi padi.

\section{METODOLOGI}

Penelitian dilaksanakan di Desa Cipta Karya, Kecamatan Sungai Betung, Kabupaten Bengkayang dengan waktu penelitian dilaksanakan selama lima bulan sejak Februari sampai Juni 2020. Bahanbahan yang digunakan dalam penelitian ini adalah benih padi varietas Cilosari, Ciherang, Inpari 39 dan Inpago 8, tanah aluvial, ember, pupuk Urea, pupuk $\mathrm{KCl}$, pupuk SP-36, insektisida dan fungisida. Peralatan yang digunakan antara lain: termohygrometer untuk mengukur suhu dan kelembaban, timbangan analitik, meteran, penggaris dan kamera. Data curah hujan diperoleh dari stasiun Klimatologi Siantan Pontianak, Kalimantan Barat. Penelitian ini menggunakan metode eksperimen lapangan dengan pola Rancangan Acak Lengkap Faktorial (RALF) yang terdiri dari 2 faktor. Faktor pertama adalah varietas padi (V) sebanyak 4 taraf yaitu varietas Cilosari, Ciherang, Inpari 39 dan Inpago 8 dan faktor kedua adalah tinggi muka air (A) sebanyak 5 taraf yaitu $-5 \mathrm{~cm}, 0 \mathrm{~cm}, 5 \mathrm{~cm}, 10 \mathrm{~cm}$ dan $15 \mathrm{~cm}$. Percobaan diulang sebanyak 3 kali dengan masing-masing perlakuan terdapat 3 sampel tanaman sehingga keseluruhan berjumlah 180 unit percobaan. Pengamatan terhadap peubah : 1). Komponen pertumbuhan yaitu tinggi tanaman dan jumlah anakan maksimum, 2). Komponen hasil meliputi jumlah anakan produktif, umur berbunga, jumlah gabah isi per malai, panjang malai, persentase gabah isi per malai, bobot 1.000 butir dan bobot gabah kering panen per rumpun. Data hasil pengamatan tiap parameter yang dianalisis menggunakan uji $\mathrm{F}$ pada taraf nyata $5 \%$, apabila hasil analisis terdapat pengaruh perbedaan yang nyata di antara perlakuan, maka dilakukan uji lanjut menggunakan BNT $5 \%$ untuk mengetahui perbedaan pada masing-masing perlakuan.

\section{HASIL DAN PEMBAHASAN}

Tabel 1 memperlihatkan bahwa pada umur 28 hari setelah tanam (HST), hanya perlakuan tinggi muka air yang memberikan pengaruh yang nyata terhadap tinggi tanaman. Tinggi muka air $5 \mathrm{~cm}$ dan $10 \mathrm{~cm}$ memberikan tinggi tanaman lebih tinggi yaitu $51,53 \mathrm{~cm}$ dan $51,64 \mathrm{~cm}$ dibandingkan dengan perlakuan tinggi muka air lainnya. Varietas Inpari 39 menunjukkan tinggi tanaman tertinggi dan berbeda nyata dibandingkan varietas Cilosari. Namun, varietas Ciherang dan Inpago 8 tidak berpengaruh nyata terhadap tinggi tanaman.

Perlakuan tinggi muka air $5 \mathrm{~cm}$ pada umur pengamatan 56 HST menghasilkan tinggi tanaman tertinggi yaitu $86,72 \mathrm{~cm}$ dan berbeda nyata dengan tinggi muka air -5 dan $15 \mathrm{~cm}$. Hal tersebut menunjukkan bahwa tanaman padi memerlukan ketersediaan air yang berbeda untuk setiap fase pertumbuhannya dan tinggi muka air 5 $\mathrm{cm}$ dan $10 \mathrm{~cm}$ mampu menciptakan kondisi pemenuhan kebutuhan air secara optimum.

Keadaan nutrien yang tersedia bagi tanaman digunakan bagi pertumbuhan tanaman yang ditunjukkan dengan meningkatnya tinggi tanaman. Hal tersebut sejalan dengan hasil penelitian Kawano et al. (2008) yang menyatakan bahwa adanya penggenangan akan memacu elongasi batang sebagai salah satu strategi penghindaran (escape strategy) terhadap penggenangan untuk membantu mencukupi kebutuhan oksigen dan karbondioksida mendukung respirasi aerob dan fotosintesis. Selanjutnya, Jackson (2003) menyatakan bahwa pertumbuhan tinggi tanaman sebagai hasil pemanjangan batang merupakan respon toleransi tanaman terhadap penggenangan. 
Tabel 1. Rerata tinggi tanaman pada beberapa varietas padi dan tinggi muka air berbeda pada umur tanaman 28 dan 56 HST

Table 1. The average of plant height of several varieties of rice and different water levels at 28 and 56 DAP (Days After Planting)

\begin{tabular}{lcc}
\hline \multirow{2}{*}{$\begin{array}{l}\text { Perlakuan } \\
\text { Treatment }\end{array}$} & $\begin{array}{c}\text { Tinggi tanaman }(\mathrm{cm}), \text { pada umur pengamatan ke- (HST) } \\
\text { Plant height }(\mathrm{cm}) \text {, at the age of observation of }(D A P)\end{array}$ \\
\cline { 2 - 3 } & 28 & 56 \\
\hline Varietas & & \\
\hline Cilosari & 45,77 & $73,31 \mathrm{a}$ \\
Ciherang & 47,51 & $81,68 \mathrm{ab}$ \\
Inpari 39 & 45,51 & $84,33 \mathrm{~b}$ \\
Inpago 8 & 48,31 & $81,78 \mathrm{ab}$ \\
\hline BNT 5\% & tn & 9,89 \\
\hline Tinggi Muka Air & & $76,19 \mathrm{a}$ \\
\hline Tinggi Muka Air $-5 \mathrm{~cm}$ & $42,86 \mathrm{a}$ & $78,96 \mathrm{ab}$ \\
Tinggi Muka Air 0 cm & $44,51 \mathrm{a}$ & $86,72 \mathrm{~b}$ \\
Tinggi Muka Air $5 \mathrm{~cm}$ & $51,53 \mathrm{~b}$ & $83,75 \mathrm{ab}$ \\
Tinggi Muka Air $10 \mathrm{~cm}$ & $51,64 \mathrm{~b}$ & $75,76 \mathrm{a}$ \\
Tinggi Muka Air $15 \mathrm{~cm}$ & $43,34 \mathrm{a}$ & 9,65 \\
\hline BNT 5 \% & 5,48 &
\end{tabular}

Keterangan : Nilai yang didampingi huruf yang sama menunjukkan tidak berbeda nyata menurut uji BNT 5\%.

Hasil interaksi perlakuan varietas dan tinggi muka air pada Tabel 2 menunjukkan bahwa pada varietas Cilosari umur $42 \mathrm{HST}$, tinggi muka air $10 \mathrm{~cm}$ memberikan tinggi tanaman lebih tinggi yaitu sebesar $72,71 \mathrm{~cm}$ dibandingkan perlakuan tinggi muka air lainnya. Untuk varietas Ciherang, pada umur 42 HST, tinggi tanaman tertinggi terlihat pada tinggi muka air $5 \mathrm{~cm}$ dan $10 \mathrm{~cm}$ yaitu $82,41 \mathrm{~cm}$ dan $80,33 \mathrm{~cm}$. Sementara, varietas Inpari 39 memiliki tinggi tanaman yang sama dan tidak berbeda pada semua perlakuan tinggi muka air. Pada varietas Inpago 8, erlakuan tinggi muka air $5 \mathrm{~cm}$ pada memberikan tinggi tanaman lebih tinggi yaitu $82,54 \mathrm{~cm}$ dibandingkan perlakuan tinggi muka air -5 $\mathrm{cm}, 0 \mathrm{~cm}$ dan $15 \mathrm{~cm}$, tetapi tidak berbeda nyata dengan perlakuan tinggi muka air 10 $\mathrm{cm}$.

Varietas Inpari 39 pada tinggi muka air $-5 \mathrm{~cm}$ memiliki tinggi tanaman tertinggi $(137,90 \mathrm{~cm})$ diantara empat varietas yang diuji pada umur 70 HST (Tabel 2). Pada tinggi muka air $0 \mathrm{~cm}$ terlihat bahwa varietas Inpari 39 dan Ciherang memberikan tinggi tanaman tertinggi dan berbeda yaitu $145,71 \mathrm{~cm}$ dan $136,68 \mathrm{~cm}$. Sedangkan pada tinggi muka air $5 \mathrm{~cm}$, varietas Cilosari dan Inpago 8 memiliki tinggi tanaman tertinggi $(119,88 \mathrm{~cm}$ dan $122,02 \mathrm{~cm})$ dan berbeda nyata dibandingkan varietas Ciherang namun memiliki tinggi tanaman yang sama dengan varietas Inpari 39. Akan tetapi pada perlakuan tinggi muka air $10 \mathrm{~cm}$, ketiga varietas yang diuji yaitu Cilosari, Inpari 39 dan Inpago 8 tidak berbeda nyata berdasarkan hasil uji lanjut, sedangkan varietas Ciherang memiliki tinggi tanaman lebih tinggi yaitu $123,18 \mathrm{~cm}$. Namun demikian, pada perlakuan $15 \mathrm{~cm}$ terlihat bahwa keempat varietas yang diuji menunjukkan tinggi tanaman yang tidak berbeda berdasarkan hasil uji lanjut.

Menurut Gardner et al. (2008), tinggi rendahnya pertumbuhan serta hasil tanaman dipengaruhi oleh dua faktor, yaitu faktor internal dan faktor eksternal. Faktor internal merupakan faktor yang 
dipengaruhi oleh sifat genetik atau sifat turunan seperti usia tanaman, morfologi tanaman, daya hasil, kapasitas menyimpan cadangan makanan, ketahanan terhadap penyakit dan lain-lain. Faktor eksternal merupakan faktor lingkungan, seperti iklim, tanah dan faktor biotik. Tinggi tanaman termasuk ciri tanaman padi yang dipengaruhi oleh gen dari dalam tubuh tanaman itu sendiri.

Tabel 2. Rerata tinggi tanaman akibat interaksi perlakuan varietas padi dan tinggi muka air pada umur tanaman 42 dan 70 HST

Table 2. The average plant height under the interaction between rice variety and water level at 42 and $70 \mathrm{DAP}$

\begin{tabular}{|c|c|c|c|c|}
\hline \multirow[t]{2}{*}{$\begin{array}{l}\text { Perlakuan } \\
\text { Treatment }\end{array}$} & \multicolumn{4}{|c|}{$\begin{array}{l}\text { Tinggi tanaman (cm), pada umur pengamatan } \\
\text { (HST) } \\
\text { Plant height }(\mathrm{cm}) \text {, at the age of observation (DAP) }\end{array}$} \\
\hline & \multicolumn{2}{|c|}{42} & \multicolumn{2}{|c|}{70} \\
\hline Cilosari + Tinggi muka air $-5 \mathrm{~cm}$ & 51,19 & $\mathrm{a}$ & 124,98 & $\mathrm{~g}$ \\
\hline Cilosari + Tinggi muka air $0 \mathrm{~cm}$ & 60,80 & abcd & 119,09 & defg \\
\hline Cilosari + Tinggi muka air $5 \mathrm{~cm}$ & 62,32 & abcd & 119,88 & efg \\
\hline Cilosari + Tinggi muka air $10 \mathrm{~cm}$ & 72,71 & def & 110,17 & $\mathrm{abc}$ \\
\hline Cilosari + Tinggi muka air $15 \mathrm{~cm}$ & 52,30 & $\mathrm{ab}$ & 111,72 & abcd \\
\hline Ciherang + Tinggi muka air $-5 \mathrm{~cm}$ & 57,68 & $a b c$ & 116,56 & cdef \\
\hline Ciherang + Tinggi muka air $0 \mathrm{~cm}$ & 64,13 & abcd & 136,68 & $\mathrm{~h}$ \\
\hline Ciherang + Tinggi muka air $5 \mathrm{~cm}$ & 82,41 & $\mathrm{f}$ & 109,20 & $\mathrm{abc}$ \\
\hline Ciherang + Tinggi muka air $10 \mathrm{~cm}$ & 80,33 & ef & 123,18 & fg \\
\hline Ciherang + Tinggi muka air $15 \mathrm{~cm}$ & 55,39 & $a b c$ & 104,13 & $\mathrm{a}$ \\
\hline Inpari $39+$ Tinggi muka air $-5 \mathrm{~cm}$ & 68,56 & cdef & 137,90 & $\mathrm{~h}$ \\
\hline Inpari $39+$ Tinggi muka air $0 \mathrm{~cm}$ & 62,41 & abcd & 145,71 & $\mathrm{i}$ \\
\hline Inpari $39+$ Tinggi muka air $5 \mathrm{~cm}$ & 61,16 & abcd & 114,76 & cde \\
\hline Inpari $39+$ Tinggi muka air $10 \mathrm{~cm}$ & 62,48 & abcd & 104,62 & $a b$ \\
\hline Inpari $39+$ Tinggi muka air $15 \mathrm{~cm}$ & 57,43 & $a b c$ & 109,81 & $a b c$ \\
\hline Inpago $8+$ Tinggi muka air $-5 \mathrm{~cm}$ & 56,94 & $a b c$ & 120,90 & efg \\
\hline Inpago $8+$ Tinggi muka air $0 \mathrm{~cm}$ & 66,76 & cde & 121,54 & efg \\
\hline Inpago $8+$ Tinggi muka air $5 \mathrm{~cm}$ & 82,54 & $\mathrm{f}$ & 122,02 & efg \\
\hline Inpago $8+$ Tinggi muka air $10 \mathrm{~cm}$ & 73,59 & def & 106,91 & $a b$ \\
\hline Inpago $8+$ Tinggi muka air $15 \mathrm{~cm}$ & 66,42 & bcde & 112,08 & bcd \\
\hline BNT 5\% & 14,40 & & 7,59 & \\
\hline
\end{tabular}

Keterangan : Nilai yang didampingi huruf yang sama menunjukkan tidak berbeda nyata menurut uji BNT 5\%.

Data jumlah anakan maksimum per rumpun berdasarkan hasil analisis sidik ragam menunjukkan pada pengamatan 28 HST terjadi interaksi antara perlakuan varietas dan tinggi muka air sedangkan pada umur 42 hanya perlakuan tinggi muka air yang berpengaruh nyata, umur 56 dan 70 HST memperlihatkan kedua perlakuan berpengaruh nyata.
Hasil penelitian memperlihatkan bahwa pada perlakuan tinggi muka air 5 $\mathrm{cm}$, varietas Cilosari, Ciherang dan Inpari 39 memiliki jumlah anakan maksimum yang sama pada umur 28, 42 dan 56 HST, tetapi lebih tinggi jika dibandingkan varietas Inpago 8. Parameter jumlah anakan maksimum tertinggi pada perlakuan tinggi muka air $10 \mathrm{~cm}$ 
ditunjukkan varietas Ciherang dan Inpari 39 yaitu masing-masing sebesar $7,89 \mathrm{~cm}$ dan $8,78 \mathrm{~cm}$. Dari hasil tersebut, diketahui bahwa perlakuan tinggi muka air 5 dan 10 $\mathrm{cm}$ menghasilkan jumlah anakan maksimum tertinggi. Hal ini didukung oleh pendapat Vergara (1976) bahwa kebutuhan air bagi tanaman padi pada awal fase vegetatif yang merupakan fase pembentukan anakan aktif dan maksimum adalah kritis. Sulistyono et al. (2012) menyatakan, padi merupakan tanaman yang sangat sensitif terhadap cekaman kekeringan. Kekeringan akan mengakibatkan penurunan jumlah anakan. Perlakuan tinggi muka air 5 dan $10 \mathrm{~cm}$ mampu mendukung varietas Cilosari, Ciherang dan Inpari 39 menghasilkan anakan maksimum tertinggi. Sedangkan tinggi muka air $-5 \mathrm{~cm}$ hanya varietas Inpari 39 yang mampu menghasilkan jumlah anakan maksimum tertinggi, hal ini diduga dipengaruhi faktor genetik, yaitu toleran terhadap kekeringan.

Tabel 3. Rerata jumlah anakan maksimum akibat interaksi perlakuan varietas padi dan tinggi muka air pada umur tanaman 28 HST.

Table 3. The average of maximum tiller numbers under the interaction between rice variety and water level at $28 D A P$

\begin{tabular}{|c|c|}
\hline $\begin{array}{l}\text { Perlakuan } \\
\text { Treatment }\end{array}$ & $\begin{array}{l}\text { Jumlah anakan pada umur pengamatan } 28 \mathrm{HST} \\
\text { The number of tillers at the age of observation } \\
28 \mathrm{DAP}\end{array}$ \\
\hline Cilosari + Tinggi muka air $-5 \mathrm{~cm}$ & 5,44 abc \\
\hline Cilosari + Tinggi muka air $0 \mathrm{~cm}$ & 6,11 bcdef \\
\hline Cilosari + Tinggi muka air $5 \mathrm{~cm}$ & $8,11 \mathrm{jk}$ \\
\hline Cilosari + Tinggi muka air $10 \mathrm{~cm}$ & 6,89 efghi \\
\hline Cilosari + Tinggi muka air $15 \mathrm{~cm}$ & 5,56 abcd \\
\hline Ciherang + Tinggi muka air $-5 \mathrm{~cm}$ & $5,33 \mathrm{ab}$ \\
\hline Ciherang + Tinggi muka air $0 \mathrm{~cm}$ & 6,44 cdefg \\
\hline Ciherang + Tinggi muka air $5 \mathrm{~cm}$ & 7,67 hij \\
\hline Ciherang + Tinggi muka air $10 \mathrm{~cm}$ & 7,89 ijk \\
\hline Ciherang + Tinggi muka air $15 \mathrm{~cm}$ & 5,67 abcd \\
\hline Inpari $39+$ Tinggi muka air $-5 \mathrm{~cm}$ & 7,22 ghij \\
\hline Inpari $39+$ Tinggi muka air $0 \mathrm{~cm}$ & $8,78 \mathrm{k}$ \\
\hline Inpari $39+$ Tinggi muka air $5 \mathrm{~cm}$ & 7,11 fghij \\
\hline Inpari $39+$ Tinggi muka air $10 \mathrm{~cm}$ & $8,11 \mathrm{jk}$ \\
\hline Inpari $39+$ Tinggi muka air $15 \mathrm{~cm}$ & 4,89 a \\
\hline Inpago $8+$ Tinggi muka air $-5 \mathrm{~cm}$ & 6,00 bcde \\
\hline Inpago $8+$ Tinggi muka air $0 \mathrm{~cm}$ & 6,44 cdefg \\
\hline Inpago $8+$ Tinggi muka air $5 \mathrm{~cm}$ & 6,56 defg \\
\hline Inpago $8+$ Tinggi muka air $10 \mathrm{~cm}$ & 6,78 efgh \\
\hline Inpago $8+$ Tinggi muka air $15 \mathrm{~cm}$ & 5,89 abcde \\
\hline BNT $5 \%$ & 1,09 \\
\hline
\end{tabular}

Keterangan : Nilai yang didampingi huruf yang sama menunjukkan tidak berbeda nyata menurut uji BNT 5\%.

Pembentukan jumlah anakan maksimum pada umur 70 HST fase reproduktif varietas Cilosari dan Inpari 39 lebih tinggi dibandingkan varietas Ciherang, tetapi memiliki jumlah anakan yang sama dengan Inpago 8. Di sisi lain, 
perlakuan tinggi muka air $-5,0,5,10 \mathrm{~cm}$ menghasilkan jumlah anakan maksimum tertinggi sementara tinggi muka air $15 \mathrm{~cm}$ menghasilkan jumlah anakan terendah. Prastowo (2010) menyatakan bahwa kebutuhan air konsumtif dipengaruhi oleh jenis dan umur tanaman (fase pertumbuhan tanaman). Pada saat tanaman mulai tumbuh, nilai kebutuhan air konsumtif meningkat sesuai pertumbuhannya dan mencapai maksimum pada saat pertumbuhan vegetasi maksimum. Setelah mencapai pertumbuhan maksimum, nilai kebutuhan air konsumtif akan menurun sejalan dengan pematangan biji. Hal ini didukung pula oleh Subagyono et al. (2004) dan Ibrahim (2008) yang menyatakan bahwa pada fase vegetatif konsumsi air tanaman lebih banyak untuk tanaman padi karena air sangat dibutuhkan untuk pembentukan anakan. Kebutuhan air berkurang ketika fase generatif dan meningkat kembali pada fase pemasakan biji.

Tabel 4. Rerata jumlah anakan maksimum pada beberapa varietas padi dan tinggi muka air yang berbeda pada umur tanaman 42 HST, 56 HST dan 70 HST

Table 4. The average of maximum tiller numbers of several varieties of rice and different water levels at 42, 56 and 70 DAP

\begin{tabular}{|c|c|c|c|}
\hline \multirow[t]{2}{*}{$\begin{array}{l}\text { Perlakuan } \\
\text { Treatment }\end{array}$} & \multicolumn{3}{|c|}{$\begin{array}{l}\text { Jumlah anakan maksimum pada umur pengamatan } \\
\text { ke-(HST) } \\
\text { The number of tillers, at the age of observation (DAP) }\end{array}$} \\
\hline & 42 & 56 & 70 \\
\hline \multicolumn{4}{|l|}{ Varietas } \\
\hline Cilosari & 17,62 & $26,24 \mathrm{~b}$ & $26,64 \mathrm{~b}$ \\
\hline Ciherang & 18,22 & $20,64 \mathrm{a}$ & $21,00 \mathrm{a}$ \\
\hline Inpari 39 & 18,27 & $26,00 \mathrm{~b}$ & $26,22 \mathrm{~b}$ \\
\hline Inpago 8 & 19,38 & $23,96 \mathrm{ab}$ & $24,44 \mathrm{ab}$ \\
\hline BNT $5 \%$ & tn & 5,36 & 4,76 \\
\hline \multicolumn{4}{|l|}{ Tinggi Muka Air } \\
\hline Tinggi Muka Air $-5 \mathrm{~cm}$ & $15,97 \mathrm{a}$ & $24,86 \mathrm{a}$ & $25,06 \mathrm{~b}$ \\
\hline Tinggi Muka Air $0 \mathrm{~cm}$ & $16,97 \mathrm{a}$ & $26,61 \mathrm{ab}$ & $27,44 \mathrm{~b}$ \\
\hline Tinggi Muka Air $5 \mathrm{~cm}$ & $22,39 \mathrm{~b}$ & $25,75 \mathrm{~b}$ & $26,28 \mathrm{~b}$ \\
\hline Tinggi Muka Air $10 \mathrm{~cm}$ & $21,17 \mathrm{~b}$ & $24,61 \mathrm{~b}$ & $24,64 \mathrm{~b}$ \\
\hline Tinggi Muka Air $15 \mathrm{~cm}$ & $15,36 \mathrm{a}$ & $19,22 \mathrm{a}$ & $19,67 \mathrm{a}$ \\
\hline BNT $5 \%$ & 4,10 & 5,22 & 4,64 \\
\hline
\end{tabular}

Keterangan : Nilai yang didampingi huruf yang sama menunjukkan tidak berbeda nyata menurut uji BNT 5\%.

\section{Komponen Hasil}

Hasil analisis sidik ragam perlakuan varietas dan tinggi muka air memberikan pengaruh terhadap parameter jumlah anakan produktif, umur berbunga, dan jumlah gabah isi per malai, persentase gabah isi per malai, bobot 1.000 butir dan bobot gabah kering panen per rumpun. Sedangkan pada parameter pengamatan panjang malai, hanya perlakuan varietas yang menunjukkan perbedaan yang nyata. Data jumlah anakan produktif, umur berbunga dan jumlah gabah isi per malai disajikan pada Tabel 5 .

Data pada Tabel 5 menunjukkan bahwa dari keempat varietas yang diuji, jumlah anakan produktif tertinggi dihasilkan pada varietas Cilosari $(23,16)$, Inpari $39(23,07)$ dan Inpago $8(22,96)$. Hasil perlakuan tinggi muka air $0 \mathrm{~cm}, 5 \mathrm{~cm}$ 
dan $10 \mathrm{~cm}$ memperlihatkan jumlah anakan produktif yang tidak berbeda nyata, tetapi lebih tinggi jika dibandingkan dengan perlakuan tinggi muka air $-5 \mathrm{~cm}$ dan 15 $\mathrm{cm}$. Menurut Hasanuddin (2004), produksi suatu malai merupakan salah satu penambahan berat kering suatu tanaman. Besar kecilnya produksi malai suatu tanaman sangat tergantung pada faktorfaktor pertumbuhan. Ditambahkan oleh Riyanto et al. (2012), bahwa karakter jumlah anakan total per rumpun hanya memiliki korelasi positif dan nyata dengan karakter jumlah anakan produktif per rumpun dan berkorelasi negatif dan nyata dengan bobot 100 biji. Artinya, tanaman yang memiliki jumlah anakan total per rumpun yang banyak akan memiliki jumlah anakan produktif yang banyak

Parameter pengamatan umur berbunga pada Tabel 5 menunjukkan perlakuan varietas Cilosari memiliki umur berbunga tertinggi yaitu $82,69 \mathrm{HST}$. Hal ini didukung dari deskripsi varietas pada Lampiran 2 bahwa varietas Cilosari mempunyai umur yang panjang yaitu \pm 125 hari. Menurut Lakitan (2007), umur berbunga pada tanaman tidaklah hanya dipengaruhi oleh suatu perlakuan saja akan tetapi juga dipengaruhi oleh lingkungan lainnya maupun genetik. Pembungaan merupakan fenomena fisiologi yang tidak sederhana, perubahan fase vegetatif menjadi generatif merupakan suatu perubahan yang sangat besar karena struktur jaringannya berbeda sekali. Selain itu, varietas yang digunakan juga mempengaruhi pembungaan.

Perlakuan tinggi muka air $5 \mathrm{~cm}$ memiliki umur berbunga tertinggi yaitu 80,28 HST, sedangkan perlakuan muka air $-5 \mathrm{~cm}, 0 \mathrm{~cm}, 10 \mathrm{~cm}$ dan $15 \mathrm{~cm}$ menghasilkan umur berbunga yang paling lama. Hal ini diduga karena pada perlakuan $-5 \mathrm{~cm}$ dan $0 \mathrm{~cm}$, tanaman mengalami kekurangan air dan perlakuan $10 \mathrm{~cm}$ dan 15 $\mathrm{cm}$ tanaman mengalami kelebihan air. Menurut Lisar et al. (2012), akibat dari cekaman kekeringan pada tanaman adalah penutupan stomata, penurunan laju fotosintesis dan laju transpirasi, penurunan laju penyerapan dan translokasi nutrient (unsur hara), penurunan pemanjangan sel serta penghambatan pertumbuhan. Akibat dari penutupan stomata, pengambilan karbondioksida dan produksi berat kering menurun.

Data parameter jumlah gabah isi per malai pada Tabel 5 memperlihatkan bahwa dari keempat varietas yang diuji, varietas Ciherang memiliki jumlah gabah isi per malai lebih rendah yaitu sebesar 95,87 dibandingkan varietas Cilosari, Inpari 39 dan Inpago 8. Sedangkan perlakuan tinggi muka air $5 \mathrm{~cm}$ menunjukkan jumlah gabah isi tertinggi yaitu sebesar 132,06 dibandingkan perlakuan tinggi muka air -5 $\mathrm{cm}, 0 \mathrm{~cm}$ dan $15 \mathrm{~cm}$. Rendahnya jumlah gabah isi varietas Ciherang disebabkan tingginya persentase gabah hampa akibat serangan walang sangit. Pada perlakuan tinggi muka air $5 \mathrm{~cm}$ menunjukkan jumlah gabah isi tertinggi yaitu sebesar 132,06 dibandingkan perlakuan tinggi muka air -5 $\mathrm{cm}, 0 \mathrm{~cm}$ dan $15 \mathrm{~cm}$. Hal ini diduga pemberian tinggi muka air $5 \mathrm{~cm}$ memberikan ketersediaan air yang cukup untuk kebutuhan tanaman pada fase vegetatif dan mengurangi terjadinya plasmolisis, sehingga saat memasuki fase generatif, ketersediaan air yang cukup mampu mengoptimalkan proses fotosintesis yang mengakibatkan proses pengisian gabah menjadi lebih optimal. Menurut Bouman et al. (2005), kekurangan dan kelebihan air dapat mengganggu proses metabolisme bahkan akan mematikan tanaman. Pengairan yang diberikan secara kecukupan akan memberi kesempatan kepada akar untuk berkembang menjadi lebih baik.

Data parameter panjang malai pada Tabel 6 menunjukkan bahwa hanya perlakuan varietas yang memberikan perbedaan, sedangkan perlakuan tinggi muka air tidak berpengaruh nyata. Dari 
keempat varietas yang diuji, yang memiliki panjang malai terendah yaitu varietas Ciherang sebesar $22,27 \mathrm{~cm}$. Sedangkan ketiga varietas lainnya, yaitu Cilosari, Inpari 39 dan Inpago 8 memberikan panjang malai yang tidak berbeda, tetapi lebih tinggi jika dibandingkan dengan varietas Ciherang. Menurut Yoshida (1981), tinggi tanaman dan jumlah anakan produktif merupakan salah satu karakter tanaman yang mempunyai pengaruh yang besar terhadap hubungan antara panjang malai dan hasil. Tanaman yang tumbuh baik mampu menyerap hara secara optimal, sehingga pada lingkungan tumbuh yang ketersediaan air dan haranya cukup dapat meningkatkan aktivitas fotosintesis tanaman, sehingga pertumbuhan hasil tanaman meningkat.

Tabel 5. Rerata jumlah anakan produktif, umur berbunga dan jumlah gabah isi per malai akibat pengaruh varietas dan tinggi muka air

Table 5. The average of productive tiller number, flowering age, and the number of filled grain per panicle of several varieties of rice and different water levels

\begin{tabular}{|c|c|c|c|}
\hline $\begin{array}{l}\text { Perlakuan } \\
\text { Treatment }\end{array}$ & $\begin{array}{l}\text { Jumlah Anakan } \\
\text { Produktif } \\
\text { The number of } \\
\text { productive tillers }\end{array}$ & $\begin{array}{c}\text { Umur Berbunga } \\
\text { (HST) } \\
\text { Flowering age } \\
(D A P)\end{array}$ & $\begin{array}{l}\text { Jumlah gabah Isi } \\
\text { Per Malai } \\
\text { The number of } \\
\text { filled grains per } \\
\text { panicle }\end{array}$ \\
\hline \multicolumn{4}{|l|}{ Varietas } \\
\hline Cilosari & $23,16 b$ & $82,69 \mathrm{~b}$ & $120,13 b$ \\
\hline Ciherang & $18,04 \mathrm{a}$ & $75,80 \mathrm{a}$ & $95,87 \mathrm{a}$ \\
\hline Inpari 39 & $23,07 \mathrm{~b}$ & $75,09 \mathrm{a}$ & $117,33 \mathrm{~b}$ \\
\hline Inpago8 & $22,96 \mathrm{~b}$ & $72,53 \mathrm{a}$ & $115,31 \mathrm{~b}$ \\
\hline BNT $5 \%$ & 3,98 & 3,90 & 18,09 \\
\hline \multicolumn{4}{|l|}{ Tinggi Muka Air } \\
\hline Tinggi Muka Air $-5 \mathrm{~cm}$ & $21,45 \mathrm{a}$ & $75,78 \mathrm{ab}$ & $94,44 \mathrm{a}$ \\
\hline Tinggi Muka Air $0 \mathrm{~cm}$ & $23,86 \mathrm{~b}$ & $78,83 \mathrm{bc}$ & $113,86 \mathrm{~b}$ \\
\hline Tinggi Muka Air $5 \mathrm{~cm}$ & $24,44 \mathrm{~b}$ & $80,28 \mathrm{c}$ & $132,06 \mathrm{c}$ \\
\hline Tinggi Muka Air $10 \mathrm{~cm}$ & $21,67 \mathrm{~b}$ & $73,92 \mathrm{a}$ & $115,47 \mathrm{bc}$ \\
\hline Tinggi Muka Air $15 \mathrm{~cm}$ & $17,58 \mathrm{a}$ & $73,83 \mathrm{a}$ & $104,97 \mathrm{a}$ \\
\hline BNT $5 \%$ & 3,88 & 3,81 & 17,65 \\
\hline
\end{tabular}

Keterangan : Nilai yang didampingi huruf yang sama menunjukkan tidak berbeda nyata menurut uji BNT 5\%. Note: lowercase (vertical) and capital letters (horizontal). Numbers followed by different letters show a significant difference according to the 5\% DMRT test.

Perlakuan varietas dan tinggi muka air berpengaruh terhadap parameter persentase gabah isi per malai (Tabel 6). Perlakuan Varietas Cilosari, Inpari 39 dan Inpago 8 menghasilkan persentase gabah isi per malai tertinggi yaitu masing-masing sebesar $81,13 \%, 81,05 \%$ dan 81,07\%, dibandingkan varietas Ciherang dengan persentase gabah isi per malai sebesar $70,75 \%$. Sedangkan perlakuan tinggi muka air $0 \mathrm{~cm}$ dan $5 \mathrm{~cm}$ memiliki persentase gabah isi tertinggi, yaitu masing-masing sebesar $84,65 \%$ dan 86,73 $\%$ dan berbeda nyata dengan perlakuan tinggi muka air $-5 \mathrm{~cm}, 10 \mathrm{~cm}$ dan $15 \mathrm{~cm}$.

Tabel 6 menunjukkan bahwa perlakuan varietas dan tinggi muka air berpengaruh pada bobot 1.000 butir dan bobot gabah kering panen per rumpun. Perlakuan varietas Cilosari, Inpari 39 dan Inpago 8 menunjukkan bobot 1.000 butir dan gabah kering panen per rumpun lebih 
tinggi jika dibandingkan dengan varietas Ciherang. Sedangkan perlakuan tinggi muka air $5 \mathrm{~cm}$ untuk parameter bobot 1.000 butir dan gabah kering panen lebih tinggi jika dibandingkan dengan tinggi muka air $5 \mathrm{~cm}, 0 \mathrm{~cm}$ dan $15 \mathrm{~cm}$. Menurut Munns (2002), secara fisiologis, tanaman-tanaman yang tumbuh pada kondisi cekaman kekeringan akan mengurangi laju stomata sehingga akan menurunkan laju kehilangan air yang diikuti dengan penutupan stomata dan menurunnya serapan $\mathrm{CO} 2$ bersih pada daun. Hal ini akan menyebabkan menurunnya laju fotosintesis serta fosintat yang dihasilkan.

Tabel 6. Rerata panjang malai, persentase gabah isi per malai, bobot 1.000 butir, dan bobot gabah kering panen per rumpun akibat pengaruh varietas dan tinggi muka air

Table 6. The average of panicle length, percentage of filled grain per panicle, weight of 1000 grains, and weight of harvested dry grain per clump of several varieties of rice and different water levels

\begin{tabular}{|c|c|c|c|c|}
\hline $\begin{array}{l}\text { Perlakuan } \\
\text { Treatment }\end{array}$ & $\begin{array}{l}\text { Panjang } \\
\text { Malai } \\
\text { (cm) } \\
\text { Panicle } \\
\text { length } \\
\text { (cm) }\end{array}$ & $\begin{array}{c}\text { Persentase } \\
\text { Gabah Isi } \\
\text { Per Malai } \\
(\%) \\
\text { Percentage } \\
\text { offilled } \\
\text { grain per } \\
\text { panicle (\%) }\end{array}$ & $\begin{array}{l}\text { Bobot } 1.000 \\
\text { Butir }(\mathrm{g}) \\
\text { Weight of } \\
1000 \text { grains } \\
(\mathrm{g})\end{array}$ & $\begin{array}{c}\text { Bobot Gabah } \\
\text { Kering Panen } \\
\text { Per Rumpun (g) } \\
\text { Weight of } \\
\text { harvested dry } \\
\text { grain per clump } \\
\text { (g) }\end{array}$ \\
\hline \multicolumn{5}{|l|}{ Varietas } \\
\hline Cilosari & $24,19 \mathrm{~b}$ & $81,13 \mathrm{~b}$ & $28,27 \mathrm{~b}$ & $36,93 \mathrm{~b}$ \\
\hline Ciherang & $22,27 \mathrm{a}$ & $70,75 \mathrm{a}$ & $24,93 \mathrm{a}$ & $25,07 \mathrm{a}$ \\
\hline Inpari 39 & $24,15 \mathrm{~b}$ & $81,05 \mathrm{~b}$ & $28,07 \mathrm{~b}$ & $32,40 \mathrm{~b}$ \\
\hline Inpago 8 & $24,96 \mathrm{~b}$ & $81,07 \mathrm{~b}$ & $28,40 \mathrm{~b}$ & $31,89 \mathrm{~b}$ \\
\hline BNT $5 \%$ & 1,70 & 10,21 & 2,95 & 6,07 \\
\hline \multicolumn{5}{|l|}{ Tinggi Muka Air } \\
\hline Tinggi Muka Air - $5 \mathrm{~cm}$ & 23,69 & $73,23 \mathrm{a}$ & $24,42 \mathrm{a}$ & $24,50 \mathrm{a}$ \\
\hline Tinggi Muka Air $0 \mathrm{~cm}$ & 23,78 & $84,65 \mathrm{~b}$ & $27,05 \mathrm{~b}$ & $30,50 \mathrm{~b}$ \\
\hline Tinggi Muka Air $5 \mathrm{~cm}$ & 24,56 & $86,73 \mathrm{~b}$ & $28,67 \mathrm{c}$ & $37,92 \mathrm{c}$ \\
\hline Tinggi Muka Air $10 \mathrm{~cm}$ & 23,60 & $74,57 \mathrm{a}$ & $27,92 \mathrm{bc}$ & $34,81 \mathrm{bc}$ \\
\hline Tinggi Muka Air $15 \mathrm{~cm}$ & 23,84 & $73,31 \mathrm{a}$ & $25,01 \mathrm{a}$ & $24,36 \mathrm{a}$ \\
\hline BNT $5 \%$ & tn & 9,96 & 2,87 & 5,92 \\
\hline
\end{tabular}

Keterangan : Nilai yang didampingi huruf yang sama menunjukkan tidak berbeda nyata menurut uji BNT 5\%.

\section{KESIMPULAN}

Varietas Cilosari, Inpari 39 dan Inpago 8 memberikan bobot gabah tertinggi yaitu masing-masing sebesar $36,93,32,40$ dan 31,89 gram per rumpun. Sedangkan tinggi muka air $5 \mathrm{~cm}$ memberikan bobot gabah tertinggi sebesar 37,92 gram per rumpun.

\section{UCAPAN TERIMA KASIH}

Makalah ini merupakan bagian dari tesis pada program pascasarjana di Universitas Tanjungpura Pontianak, sehingga penulis mengucapkan terima kasih kepada Dinas Pangan, Pertanian, Dan Perkebunan Kabupaten Bengkayang serta Pemerintah Kabupaten Bengkayang yang telah memberikan ijin tugas belajar dan 
motivasi guna melaksanakan studi dan penelitian.

\section{DAFTAR PUSTAKA}

Badan Pusat Statistik Kalimantan Barat. 期 (2018). Provinsi Kalimantan Barat dalam Angka. Badan Pusat Statistik Kalimantan Barat. https://kalbar.bps. go.id/publication/2018/08/16/83435 $3307 \mathrm{c} 31 \mathrm{~d} 74 \mathrm{c} 99 \mathrm{e} 2722 \mathrm{e} /$ provinsikalimantan-barat-dalam-angka2018.html

Bouman, B. A. M., Peng, S., Castañeda, A. 琴 R., \& Visperas, R. M. (2005). Yield and water use of irrigated tropical aerobic rice systems. Agricultural Water Management, 74(2), 87-105. https://doi.org/10.1016/j.agwat.2004 .11 .007

Bray, E. A. (2007). Plant Response to 钢 Water-deficit Stress. In Encyclopedia of Life Sciences. John Wiley \& Sons, Ltd. https://doi.org/10.1002/9780470015 902.a0001298.pub2

Gardner, F. P., Pearce, R. B., \& Mitchell, 尌 R. L. (2008). Fisiologi tanaman budidaya (H. Susilo (ed.)). UI-Press. https://library.ui.ac.id/detail?id=204 86439

Hardjowigeno, S., \& Rayes, M. L. (2005). E Tanah Sawah (Karakteristik, Kondisi, Dan Permasalahan Tanah Sawah Di Indonesia). Bayumedia Publishing.

https://elibrary.polbangtanmalang.ac .id/index.php? $\mathrm{p}=$ show_detail\&id $=18$ 61

Hasanuddin, A. (2004). Pengelolaan 尌 tanaman padi terpadu: Suatu strategi teknologi spesifik lokasi. In Makalah Panduan Pelatihan Pemasyarakatan dan Pengembangan Padi Varietas
Unggul Tipe Baru, BalitpaSukamandi, 31 Maret - 3 April 2003. Balitpa- Sukamandi.

Ibrahim, A. (2008). Prinsip-prinsip EQ Tanaman Padi Metode SRI Organik. Youth Service Foundation.

Jackson, M. B. (2003). Physiological and EQ Molecular Basis of Susceptibility and Tolerance of Rice Plants to Complete Submergence. Annals of Botany, 91(2), 227-241. https://doi.org/10.1093/aob/mcf242

Kawano, N., Ito, O., \& Sakagami, J.-I. (2008). Flash flooding resistance of rice genotypes of Oryza sativa L., O. glaberrima Steud., and Interspecific hybridization progeny. Environmental and Experimental Botany, 63(1-3), 9-18. https://doi.org/10.1016/j.envexpbot. 2007.12.001

Lakitan, B. (2007). Dasar-Dasar Fisiologi 钢 Tumbuhan. Raja Grafindo Persada. http://katalog.pustaka.unand.ac.id//i ndex.php?p=show_detail\&id $=6096$

Lisar, S. Y. S., Motafakkerazad, R., 暿 Hossain, M. M., \& Rahman, I. M. M. (2012). Water Stress in Plants: Causes, Effects and Responses. In Water Stress. InTech. Munns, R. (2002). Comparative physiology of salt and water stress. Plant, Cell \& Environment, 25(2), 239-250. https://doi.org/10.1046/j.00168025.2001.00808.x

Prastowo. (2010). Irigasi Tetes : Teori dan 尌 Aplikasi. IPB Press.

Purba, J. H. (2011). Kebutuhan dan cara pemberian air irigasi untuk tanaman padi sawah (Oryza sativa L.). WIDYATECH Jurnal Sains Dan Teknologi, 10(3), 145-155. 
https://jurnalwidyatech.files.wordpr ess.com/2012/02/jhon-hardypurba.pdf

Riyanto, A., Widiatmoko, T., \& Hartanto, B. (2012). Korelasi Antar Komponen Hasil dan Hasil pada Padi Genotip F5 Keturunan Persilangan G39 x Ciherang. Prosiding Seminar Nasional "Pengembangan Sumber Daya Pedesaan Dan Kearifan Lokal Berkelanjutan II', 8-12. http://jurnal.lppm.unsoed.ac.id/ojs/i ndex.php/Prosiding/article/viewFile/ $221 / 220$

Subagyono, K., Dariah, A., Surmaini, E., \& 钢 Kurnia, U. (2004). Pengelolaan Air pada Tanah Sawah. In F. Agus, A. Adimihardja, S. Hardjowigeno, A. M. Fagi, \& W. Hartatik (Eds.), Tanah Sawah dan Teknologi Pengelolaannya (pp. 193-226). Pusat Penelitian dan Pengembangan Tanah dan Agroklimat.

Sulistyono, E., Suwarno, Lubis, I., \& 铕 Suhendar, D. (2012). Pengaruh Frekwensi Irigasi Terhadap Pertumbuhandan Produksi Lima Galur Padi Sawah. Agrivor, 5(1), 18.

https://journal.trunojoyo.ac.id/agrovi gor/article/download/302/277

Vergara, B. S. (1976). Physiological and 钢 Morplogical Adaptability of Rice Varieties to Climate. Proceedings of The Symposium on Climate \& Rice, 67-86.

Yoshida, S. (1981). Fundamental Of Rice 咱 Crop Science. The International Rice Research Institute. http://books.irri.org/9711040522_co ntent.pdf 